$1988,37,4$

УДК 547.239 .2

А. МААСАЛУ, К. ЛЭЭТС, Т. ВЯЛИМЯЭ

\title{
РЕАКЦИЯ 3-МЕТИЛ-2-БУТЕНОНИТРИЛА С БУТАНАЛЕМ
}

A. MAASALU, K. LAATS, T. VALIMAE. 3-METUOL-2-BUTEENNITRIILI REAKTSIOON BUTANAALIGA

A. MAASALU, K. LAATS, T. VALIMAE. REACTION OF 3-METHYL-2-BUTENENITRILE WITH BUTANAL

Известно, что нитрилы, содержащие в молекуле $\alpha$-водородный атом, могут депротонироваться под действием сильных оснований и вступать в реакции с карбонильными соединениями. Продуктами реакции могут быть соответствующие $\beta$-гидроксинитрилы (продукты присоединения), $\alpha, \beta$-ненасыщенные нитрилы (продукты присоединения и дегидратации) или 1,3-дициановые соединения (продукты присоединения второй молекулы нитрила) ['] ная способность присуща и 3-метил-2-бутенонитрилу, полученному ранее [2]. В целях синтеза высших ненасыщенных нитрилов нами исследовалась реакция названного нитрила с бутаналем в присутствии $\mathrm{KOH}$. Из продукта реакции выделили с помощью препаративной ГЖХ главный и основной побочный компоненты. Первый определили как 4-гидрокси-2-метил-2-гептен-3-карбонитрил (I) - продукт присоединения исходного нитрила и альдегида, а второй как 2,2,4-триметил-3-пентен-1,3-дикарбонитрил (II) - димер 3-метил-2-бутенонитрила. Структура продуктов была установлена по данным элементного анализа, а также ИКи ${ }^{13} \mathrm{C}$-ЯМР-спектрами. Химические сдвиги ядер ${ }^{13} \mathrm{C}$ в спектрах ЯМР (рисунок) сравнимы с данными для сходной молекулярной структуры гидрокси- и ненасыщенных нитрилов [2,3].
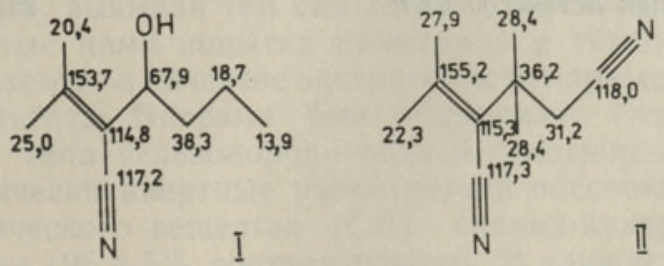

Химические сдвиги ядер ${ }^{13} \mathrm{C}$ в 4-гидрокси-2-метил-2-гептен-3-карбонитриле (I) и 2,2,4-триметил-3-пентен-1,3-дикарбонитриле (II).

Экспериментальная часть. В диэтиловом эфире (ДЭЭ) (20 мл) измельчали таблетки $85 \%$-ного КОН $(4,2$ г) и помещали смесь в трехгорлую колбу. При перемешивании добавляли 3-метил-2-бутенонитрил $(5,8$ г) и бутаналь $(5,2$ г) в ДЭЭ $(20$ мл) в течение 10 мин. Перемешивание продолжали при комнатной температуре 1 ч. После добавления воды $(20$ мл) и отслаивания в делительной воронке водный раствор экстрагировали ДЭЭ $(3 \times 5$ мл), эфирный раствор промывали водой $\left(3 \times 5\right.$ мл) и высушивали над $\mathrm{MgSO}_{4}$. После отгонки эфира перегоняли продукт реакции $\left(2,2\right.$ г) при $90-100{ }^{\circ} \mathrm{C}$ (1 мм рт. ст.), содержащий $58 \%$ I и $22 \%$ II (по ГЖX). Методом препаративной ГЖX выделили I и II c чистотой 97 и $90 \%$ соответственно. 
4-Гидрокси-2-метил-2-гептен-3-карбонитрил (I): $n_{D}^{20}$ 1,4735; ИК'спектр: $3450,2950,2225,1640,1450,1385,1075,1035 \mathrm{~cm}^{-1}$; вычислено, \%: С 70,55; Н 9,87; N 9,14; найдено, \%: С 70,0; Н 9,9; N 8,9.

2,2,4-Триметил-3-пентен-1,3-дикарбонитрил (II): $n_{D}^{20}$ 1,4795; ИКспектр: 2980,2250,2210,1620,1450, 1380, $1060 \mathrm{~cm}^{-1}$; вычислено, \%: С 74,03; Н 8,70; N 17,27; найдено, \%: С 73,8; Н 8,9; N 16,6.

ГЖХ-анализ проводили на «Цвет 6-69А» (ПИД, стеклянная колонка $47000 \times 0,3$ мм, стационарная фаза - фенилдиэтаноламинсукцинат, скорость газа-носителя (аргона) 2,5 мл/мин, температура испарителя $260^{\circ} \mathrm{C}$, термостата $\left.150^{\circ} \mathrm{C}\right)$.

Препаративную ГЖХ проводили в разреженной атмосфере газа-носителя [4] на «Хром-3» (катарометр, стеклянная колонка $3000 \times 8$ мм, $5 \%$ SE 30 на инертоне AW-HMDS 0,25-0,35 мм, давление газа-носителя (гелия) на выходе 10 мм рт. ст., температура испарителя $250{ }^{\circ} \mathrm{C}$, термостата $\left.190^{\circ} \mathrm{C}\right)$.

ИК-спектры снимали на «Specord UR-20», ${ }^{13} \mathrm{C}$-ЯMP-спектры - на WH-90 (22,63 МГц). Растворитель $\mathrm{CDCl}_{3}$, внутренний стандарт - тетраметилсилан.

\section{ЛИТЕРА Т УРА}

1. Smith, P. A. The Chemistry of Open-Chain Organic Nitrogen Compounds, 1. New York - Amsterdam, 1965, Ch. 5, 209-231.

2. Маасалу А., Вялимяэ Т., Лыйвеке И., Тенг С., Лээтс К. Синтез некоторых гидроксии ненасыщенных алифатических нитрилов. - Изв. АН ЭССР. Хим., 1988, 37, № $4,248-254$.

3. Compton, D. A. C., Murphy, W. F., Mantsch, H. H. The I. R. spectra of 3-methyl-2butenenitrile and 3-methyl-3-butenenitrile. - Spectrochim. Acta, 1981, 37A, N 6, $453-455$.

4. Сакс T., Иванов А., Самель Н. Разделение метиловых эфиров высших жирных кислот методом препаративной газовой хроматографни. 1. Предварительные опыты. - Изв. АН ЭССР. Хим., 1978, 27, № 3, 208-210.

Институт химии

Академии наук Эстонской ССР

Институт химической и биологической физики Академии наук Эстонской ССР

Поступнла в редакцию 23/III 1988 